\title{
Thermal behavior of uranyl selenite minerals derriksite and demesmaekerite
}

\author{
Vladislav V. GURZHIY'* Alina R. IZATULINA', Maria G. KRZHIZHANOVSKAYA', \\ Mikhail N. Murashko', Dar'ya V. SPIRIDONOVA², Vladimir V. SHILOVSKIKH ${ }^{3}$, \\ Sergey V. KRIVOVICHEV ${ }^{1,4}$
}

${ }^{1}$ Institute of Earth Sciences, St. Petersburg State University, University Emb. 7/9, St. Petersburg, 199034, Russian Federation; vladislav.gurzhiy@spbu.ru,vladgeo17@mail.ru

${ }^{2}$ Research Centre for X-ray Diffraction Studies, St. Petersburg State University, Universitetskiy ave. 26, St. Petersburg, 198504, Russian Federation

${ }^{3}$ Centre for Geo-Environmental Research and Modelling ("Geomodel”), St. Petersburg State University, Ulyanovskaya str. 1, St. Petersburg, 198504, Russian Federation

${ }^{4}$ Nanomaterials Research Centre, Kola Science Centre, Russian Academy of Sciences, Fersmana 14, 184209, Apatity, Russian Federation

${ }^{*}$ Corresponding author

Crystal structures of two uranyl selenite minerals derriksite, $\mathrm{Cu}_{4}\left[\left(\mathrm{UO}_{2}\right)\left(\mathrm{SeO}_{3}\right)_{2}\right](\mathrm{OH})_{6}$, and demesmaekerite, $\mathrm{Pb}_{2} \mathrm{Cu}_{5}\left[\left(\mathrm{UO}_{2}\right)_{2}\left(\mathrm{SeO}_{3}\right)_{6}(\mathrm{OH})_{6}\right]\left(\mathrm{H}_{2} \mathrm{O}\right)_{2}$, which structures are based on uranyl selenite 1D structural units, were studied employing single-crystal X-ray diffraction analysis at various temperatures. The refinement of their crystal structures reveals the detailed dynamics of the interatomic interactions during the heating process, which allows describing the thermal behavior. Uranyl selenite chains and their mutual arrangement mainly provide the rigidity of the crystal structure. Thus the lowest expansion in the structure of derriksite is observed along the direction of uranyl selenite chains, while the largest expansion occurs in the direction normal to chains, with the space occupied by lone electron pairs of $\mathrm{Se}^{4+}$ atoms and low covalent bond distribution density. The maximal expansion in the crystal structure of demesmaekerite is manifested approximately along the [100], which matches the direction of chains of less strongly bonded Cu-centered octahedra, and gaps between $\mathrm{Cu}$ chains occupied by the $\mathrm{Pb}$ cations. The crystal structure of demesmaekerite undergoes contraction in the direction of the space between the U-bearing chains with the deficiency of strong covalent bonds. Contraction of the structure can also be attributed to the orthogonalization of the oblique triclinic angles of the unit cell. It is demonstrated that the assignment of U-bearing units during structure description is reasonably justified since, regardless of their dimensionality, these substructural units are one of the most stable and rigid blocks in the structural architecture, and they govern the thermal behavior of the entire structure.

Keywords: derriksite, demesmaekerite, uranyl, selenite, crystal structure, thermal expansion

Received: 23 September 2020; accepted: 30 November 2020; handling editor: J. Pláśil

Electronic supplementary material. Supplementary crystallographic data for this paper are available online at the Journal web site (http://dx.doi.org/10.3190/jgeosci.315).

\section{Introduction}

Uranyl selenite minerals represent a rather rare group of secondary $\mathrm{U}^{6+}$-bearing natural phases that were described only in a few localities in the world. Those are, primarily, Musonoi and Shinkolobwe in DR Congo, Repete mine in Utah (USA), Zálesí deposit in the Czech Republic, Liauzun in France, and La Creusaz $\mathrm{U}$ prospect in Switzerland, and Eureka mine in Spain (Lussier et al. 2016; Gurzhiy et al. 2019a). There are seven uranyl selenite minerals known up to date: guilleminite, $\mathrm{Ba}\left[\left(\mathrm{UO}_{2}\right)_{3}\left(\mathrm{SeO}_{3}\right)_{2} \mathrm{O}_{2}\right]\left(\mathrm{H}_{2} \mathrm{O}\right)_{3}$ (Pierrot et al. 1965), demesmaekerite, $\mathrm{Pb}_{2} \mathrm{Cu}_{5}\left[\left(\mathrm{UO}_{2}\right)_{2}\left(\mathrm{SeO}_{3}\right)_{6}(\mathrm{OH})_{6}\right]\left(\mathrm{H}_{2} \mathrm{O}\right)_{2}$ (Cesbron et al. 1965), marthozite, $\mathrm{Cu}\left[\left(\mathrm{UO}_{2}\right)_{3}\left(\mathrm{SeO}_{3}\right)_{2} \mathrm{O}_{2}\right]$
$\left(\mathrm{H}_{2} \mathrm{O}\right)_{8}$ (Cesbron et al. 1969), derriksite, $\mathrm{Cu}_{4}\left[\left(\mathrm{UO}_{2}\right)\right.$ $\left.\left(\mathrm{SeO}_{3}\right)_{2}\right](\mathrm{OH})_{6}(\mathrm{Cesbron}$ et al. 1971), haynesite, $\left[\left(\mathrm{UO}_{2}\right)_{3}\left(\mathrm{SeO}_{3}\right)_{2}(\mathrm{OH})_{2}\right]\left(\mathrm{H}_{2} \mathrm{O}\right)_{5}$ (Deliens and Piret 1991), piretite, $\mathrm{Ca}\left(\mathrm{UO}_{2}\right)_{3}\left(\mathrm{SeO}_{3}\right)_{2}(\mathrm{OH})_{4} \cdot 4 \mathrm{H}_{2} \mathrm{O}$ (Vochten et al. 1996), and larisaite, $\mathrm{Na}\left(\mathrm{H}_{3} \mathrm{O}\right)\left[\left(\mathrm{UO}_{2}\right)_{3}\left(\mathrm{SeO}_{3}\right)_{2} \mathrm{O}_{2}\right]\left(\mathrm{H}_{2} \mathrm{O}\right)_{4}$ (Chukanov et al. 2004), and their characterization is far from being complete. Thus, the crystal structures of only five minerals from this group have been reported to date, while those for piretite and haynesite are still not determined, but the vibrational spectroscopy data were obtained and studied for all seven species (Vochten et al. 1996; Chukanov et al. 2004; Frost et al. 2006, 2008a,b, 2009a,b, 2014). Thermal stability of guilleminite (Pierrot et al. 1965), marthozite (Cesbron et al. 1969), derriksite 

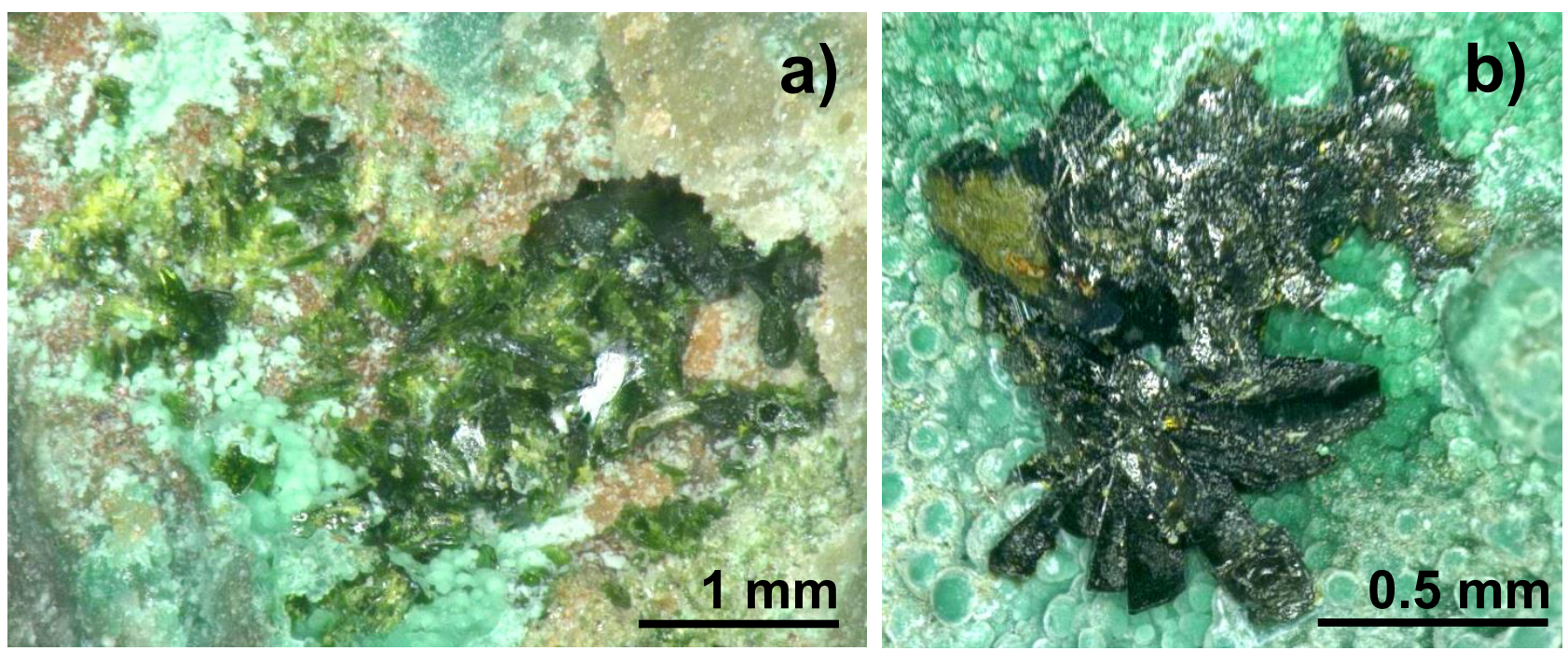

Fig. 1 Crystalline aggregates of olive-green derriksite (a) and brownish-green demesmaekerite (b) in association with light-green malachite.

(Cesbron et al. 1971) and piretite (Vochten et al. 1996) were studied using the TGA technique in the temperature range of $25-1000^{\circ} \mathrm{C}$.

With the current work, we fill in a number of crystalchemical gaps related to the named group of compounds. Single crystals of derriksite and demesmaekerite were studied using a single-crystal X-ray diffraction technique in the temperature range of -173 to $+87^{\circ} \mathrm{C}$, which allow revealing the thermal behavior of their crystal structures.

\section{Materials and methods}

\subsection{Samples and occurrence}

The single crystals of secondary uranyl selenite minerals derriksite (DER) and demesmaekerite (DEM) studied in this work (Fig. 1) were taken from the private collection of the author of the current paper (from V.V.G., sample 6111). The sample originates from the Musonoi, DR Congo.

\subsection{Chemical composition}

Small pieces of the DER and DEM single crystals verified on the diffractometer were crushed, pelletized and carbon-coated. The elemental composition of the samples was determined using a Hitachi S-3400N scanning electron microscope equipped with a AzTec Energy X-Max 20 spectrometer, with an acquisition time of $60 \mathrm{~s}$ per point (acceleration voltage $20 \mathrm{kV}$, beam current $2 \mathrm{nA}$ ) and processed with Oxford AzTec software with TrueQ technique. The following analytical standards were used: chalcopyrite $\left(\mathrm{Cu} K_{\alpha}\right)$, $\mathrm{Se}\left(\mathrm{Se}_{\alpha}\right)$, uranium containing glass $\left(\mathrm{U} M_{\alpha}\right), \mathrm{PbTe}\left(\mathrm{Pb} M_{\alpha}\right)$. Analytical calculations for DER: atomic ratio from structural data $\mathrm{Cu} 4.00, \mathrm{U} 1.00, \mathrm{Se}$
2.00; found by EDX: Cu 3.95, U 1.04, Se 2.01. Analytical calculations for DEM: atomic ratio from structural data $\mathrm{Pb} 2.00, \mathrm{Cu} 5.00, \mathrm{U} 2.00$, Se 6.00; found by EDX: $\mathrm{Pb} 2.09, \mathrm{Cu} 4.90, \mathrm{U} 2.06$, Se 5.95. Traces of Si up to 0.5 at. \% were found by EDX that can be attributed to the micro inclusions of quartz.

\subsection{Single-crystal X-ray diffraction study}

Single crystals of DER and DEM were selected under an optical microscope, encased in epoxy resin, and mounted on cryoloops. Diffraction data were collected using a Rigaku Oxford Diffraction SuperNova diffractometer equipped with an Atlas CCD detector operated with monochromated microfocused MoK $\alpha$ radiation $(\lambda=0.71073 \AA)$ at $50 \mathrm{kV}$ and $0.8 \mathrm{~mA}$. Diffraction data were collected at different temperatures without changing the crystal orientation in the range of -173 to $+87^{\circ} \mathrm{C}$ (Tab. 1) with frame widths of $1.0^{\circ}$ in $\omega$, and exposures of $22.5 \mathrm{~s}$ per frame. Data were integrated and corrected for background, Lorentz, and polarization effects. An analytical (numeric) absorption correction using a multifaceted crystal model based on expressions derived by Clark and Reid (1995) was applied in the CrysAlisPro (2018) program. The unitcell parameters (Tab. 1) were refined using least-squares techniques. The structures were solved by a dual-space algorithm and refined using the SHELX programs (Sheldrick 2015a, b) incorporated in the OLEX2 program package (Dolomanov et al. 2009). The final models included coordinates and anisotropic displacement parameters for all non- $\mathrm{H}$ atoms. The $\mathrm{H}$ atoms of $\mathrm{OH}^{-}$groups and $\mathrm{H}_{2} \mathrm{O}$ molecules were localized from difference Fourier maps and were included in the refinement with $\mathrm{U}_{\text {iso }}(\mathrm{H})$ set to $1.5 \mathrm{U}_{\text {eq }}(\mathrm{O})$ and $\mathrm{O}-\mathrm{H}$ restrained to $0.95 \AA$. Selected interatomic distances and angles are listed in the Tabs 2 and 3. Supplementary crystallographic data obtained in the 
Thermal behavior of derriksite and demesmaekerite

Tab. 1 Crystallographic data and refinement parameters for derriksite (DER) and demesmaekerite (DEM) single crystals

\begin{tabular}{|c|c|c|c|c|c|c|c|c|}
\hline Crystal & S.G. & $T\left[{ }^{\circ} \mathrm{C}\right]$ & $a[\AA] / \alpha\left[^{\circ}\right]$ & $b[\AA] / \beta\left[^{\circ}\right]$ & $c[\AA] / \gamma\left[{ }^{\circ}\right]$ & $V\left[\AA^{3}\right]$ & $R_{1}\left(\left|F_{\mathrm{O}}\right| \geq 4 \sigma F\right)$ & ICSD entry \\
\hline \multirow{8}{*}{ DER } & \multirow{8}{*}{ Pmn $2_{1}$} & -173 & $5.9679(3)$ & $5.5501(3)$ & $19.0613(9)$ & $631.35(5)$ & 0.0391 & 2033196 \\
\hline & & -120 & $5.9689(3)$ & $5.5534(4)$ & $19.0643(10)$ & $631.93(6)$ & 0.0358 & 2033197 \\
\hline & & -80 & $5.9693(2)$ & $5.5579(3)$ & $19.0674(7)$ & $632.59(5)$ & 0.0341 & 2033198 \\
\hline & & -40 & $5.9702(2)$ & $5.5629(3)$ & $19.0733(8)$ & $633.46(5)$ & 0.0368 & 2033199 \\
\hline & & 0 & $5.9720(3)$ & $5.5688(4)$ & $19.0840(11)$ & $634.67(7)$ & 0.0364 & 2033200 \\
\hline & & 30 & $5.9743(4)$ & $5.5759(4)$ & $19.0983(11)$ & $636.20(7)$ & 0.0433 & 2033201 \\
\hline & & 60 & $5.9784(3)$ & $5.5874(4)$ & $19.1254(11)$ & $638.86(7)$ & 0.0448 & 2033202 \\
\hline & & 87 & $5.9843(3)$ & $5.5966(4)$ & $19.1599(10)$ & $641.69(6)$ & 0.0472 & 2033203 \\
\hline \multirow{9}{*}{ DEM } & \multirow{9}{*}{$P-1$} & -173 & $5.6320(4) / 88.622(3)$ & $10.0417(3) / 79.572(4)$ & $11.9844(4) / 89.699(4)$ & $666.39(6)$ & 0.0337 & 2033206 \\
\hline & & -130 & $5.6406(3) / 88.638(4)$ & $10.0492(4) / 79.578(5)$ & $11.9810(8) / 89.763(4)$ & $667.73(7)$ & 0.0343 & 2033207 \\
\hline & & -90 & $5.6456(3) / 88.654(4)$ & $10.0564(4) / 79.604(4)$ & $11.9803(6) / 89.804(4)$ & $668.82(5)$ & 0.0327 & 2033208 \\
\hline & & -60 & $5.6548(3) / 88.649(4)$ & $10.0640(5) / 79.611(5)$ & $11.9794(7) / 89.824(4)$ & $670.38(7)$ & 0.0321 & 2033209 \\
\hline & & -30 & $5.6594(5) / 88.659(3)$ & $10.0663(4) / 79.634(5)$ & $11.9792(5) / 89.844(5)$ & $671.12(7)$ & 0.0348 & 2033210 \\
\hline & & 0 & $5.6611(4) / 88.658(3)$ & $10.0691(3) / 79.631(4)$ & $11.9759(4) / 89.878(4)$ & $671.31(5)$ & 0.0354 & 2033211 \\
\hline & & 30 & $5.6628(3) / 88.670(4)$ & $10.0773(4) / 79.684(4)$ & $11.9753(6) / 89.912(4)$ & $672.16(5)$ & 0.0342 & 2033212 \\
\hline & & 60 & $5.6660(3) / 88.671(3)$ & $10.0840(4) / 79.718(4)$ & $11.9746(5) / 89.932(3)$ & $673.00(5)$ & 0.0345 & 2033213 \\
\hline & & 87 & $5.6699(5) / 88.674(4)$ & $10.0953(4) / 79.773(6)$ & $11.9744(7) / 89.940(5)$ & $674.33(8)$ & 0.0361 & 2033214 \\
\hline
\end{tabular}

S.G. - space group symbol

range of -173 to $+87^{\circ} \mathrm{C}$ were deposited in the Inorganic Crystal Structure Database (ICSD) and can be obtained by quoting the depository numbers CSD 2033196-2033203 (DER) and 2033206-2033214 (DEM) via www.ccdc. cam.ac.uk/structures/. It should be noted that the crystal structures of derriksite (Ginderow and Cesbron 1983b) and demesmaekerite (Ginderow and Cesbron 1983a; Gurzhiy et al. 2019a) have been reported previously, and our studies confirm those structural models, but the use of good quality crystals and modern XRD equipment made it possible to refine the structures of minerals with higher precision.

\subsection{Thermal expansion tensor calculations}

The main coefficients of the thermal-expansion tensor were determined using a second-order approximation of temperature dependencies for the unit cell parameters by means of the TEV software (Langreiter and Kahlenberg 2015). The TEV program was also used to determine the orientation of the principal axes of the thermal expansion tensor and for the visualization of the figure of thermal expansion/contraction coefficients (TEC).

\section{Results and Discussion}

\subsection{Structure Descriptions}

There is one symmetrically unique $U$ atom in the structure of DER, forming an approximately linear $\mathrm{UO}_{2}{ }^{2+}$

Tab. 2 Selected geometrical parameters (bond lengths, $\AA$; and angles, ${ }^{\circ}$ ) in the structure of DER

\begin{tabular}{|c|c|c|c|c|c|c|}
\hline & & $-173^{\circ} \mathrm{C}$ & $87^{\circ} \mathrm{C}$ & & $-173^{\circ} \mathrm{C}$ & $87^{\circ} \mathrm{C}$ \\
\hline $\mathrm{U} 1-\mathrm{O} 1$ & & $1.802(18)$ & $1.79(3)$ & Cu3-O6 & $2.438(15)$ & $2.46(2)$ \\
\hline $\mathrm{U} 1-\mathrm{O} 2$ & & $1.776(18)$ & $1.77(3)$ & $\mathrm{Cu} 3-\mathrm{HO} 7$ & $1.973(12)$ & $1.966(14)$ \\
\hline$<\mathrm{U} 1-\mathrm{O}_{U r}>$ & & 1.789 & 1.78 & Cu3-HO8 & $2.374(16)$ & $2.39(2)$ \\
\hline U1-O3 & $\times 2$ & $2.271(12)$ & $2.284(16)$ & $\mathrm{Cu} 3-\mathrm{HO} 10$ & $1.970(10)$ & $1.972(12)$ \\
\hline $\mathrm{U} 1-\mathrm{O} 5$ & $\times 2$ & $2.315(13)$ & $2.324(17)$ & $<\mathrm{Cu} 3-\mathrm{O}>$ & 2.116 & 2.12 \\
\hline$<\mathrm{U} 1-\mathrm{O}_{e q}>$ & & 2.293 & 2.30 & & & \\
\hline $\mathrm{Se} 1-\mathrm{O} 3$ & $\times 2$ & $1.736(13)$ & $1.726(19)$ & U1-O3-Se1 & $143.2(7)$ & $143.5(12)$ \\
\hline $\mathrm{Se} 1-\mathrm{O} 4$ & & $1.666(15)$ & $1.67(2)$ & $\mathrm{U} 1-\mathrm{O} 5-\mathrm{Se} 2$ & $143.3(8)$ & $143.5(11)$ \\
\hline$<\mathrm{Se} 1-\mathrm{O}>$ & & 1.713 & 1.71 & $\mathrm{Se} 1-\mathrm{O} 4-\mathrm{Cu} 1$ & 135.7(4) & $136.0(6)$ \\
\hline Se2-O5 & $\times 2$ & $1.720(12)$ & $1.715(18)$ & $\mathrm{Se} 1-\mathrm{O} 4-\mathrm{Cu} 2$ & $122.6(8)$ & $122.4(11)$ \\
\hline $\mathrm{Se} 2-\mathrm{O} 6$ & & $1.653(15)$ & $1.64(2)$ & $\mathrm{Se} 2-\mathrm{O} 6-\mathrm{Cu} 1$ & $127.6(5)$ & $127.8(8)$ \\
\hline$<\mathrm{Se} 2-\mathrm{O}>$ & & 1.698 & 1.69 & $\mathrm{Se} 2-\mathrm{O} 6-\mathrm{Cu} 3$ & $138.8(9)$ & $138.8(12)$ \\
\hline $\mathrm{Cu} 1-\mathrm{O} 4$ & & $2.391(12)$ & $2.402(16)$ & $\mathrm{Cu} 1-\mathrm{O} 4-\mathrm{Cu} 1$ & $77.3(5)$ & $77.1(6)$ \\
\hline $\mathrm{Cu} 1-\mathrm{O} 6$ & & $2.398(13)$ & $2.436(18)$ & $\mathrm{Cu} 1-\mathrm{O} 4-\mathrm{Cu} 2$ & $83.1(4)$ & $82.8(6)$ \\
\hline $\mathrm{Cu} 1-\mathrm{HO} 7$ & & $1.982(13)$ & $2.015(15)$ & $\mathrm{Cu} 1-\mathrm{O} 6-\mathrm{Cu} 1$ & $76.9(5)$ & $75.7(6)$ \\
\hline $\mathrm{Cu} 1-\mathrm{HO} 8$ & & $1.912(10)$ & $1.914(12)$ & $\mathrm{Cu} 1-\mathrm{O} 6-\mathrm{Cu} 3$ & $82.2(4)$ & $81.5(6)$ \\
\hline $\mathrm{Cu} 1-\mathrm{HO} 9$ & & $1.922(10)$ & $1.927(13)$ & $\mathrm{Cu} 1-\mathrm{HO} 7-\mathrm{Cu} 2$ & $103.6(5)$ & $103.7(6)$ \\
\hline $\mathrm{Cu} 1-\mathrm{HO} 10$ & & $2.014(11)$ & $2.044(14)$ & $\mathrm{Cu} 3-\mathrm{HO} 7-\mathrm{Cu} 1$ & $106.9(5)$ & $106.9(7)$ \\
\hline$<\mathrm{Cu} 1-\mathrm{O}>$ & & 2.103 & 2.12 & $\mathrm{Cu} 3-\mathrm{HO} 7-\mathrm{Cu} 2$ & $97.2(5)$ & $98.0(6)$ \\
\hline $\mathrm{Cu} 2-\mathrm{O} 4$ & & $2.399(16)$ & $2.44(2)$ & $\mathrm{Cu} 1-\mathrm{HO} 8-\mathrm{Cu} 1$ & $102.4(7)$ & $102.7(9)$ \\
\hline $\mathrm{Cu} 2-\mathrm{HO} 7$ & $\times 2$ & $2.008(11)$ & $2.000(13)$ & $\mathrm{Cu} 1-\mathrm{HO} 8-\mathrm{Cu} 3$ & $93.0(5)$ & 93.3(7) \\
\hline Cu2-HO9 & & $2.267(16)$ & $2.283(19)$ & $\mathrm{Cu} 1-\mathrm{HO} 9-\mathrm{Cu} 1$ & $102.0(7)$ & $102.0(9)$ \\
\hline $\mathrm{Cu} 2-\mathrm{HO} 10$ & $\times 2$ & $1.958(10)$ & $1.969(12)$ & $\mathrm{Cu} 1-\mathrm{HO} 9-\mathrm{Cu} 2$ & $96.5(5)$ & $96.7(6)$ \\
\hline \multirow[t]{3}{*}{$<\mathrm{Cu} 2-\mathrm{O}>$} & & 2.100 & 2.11 & $\mathrm{Cu} 2-\mathrm{HO} 10-\mathrm{Cu} 1$ & $106.2(5)$ & $105.6(6)$ \\
\hline & & & & $\mathrm{Cu} 2-\mathrm{HO} 10-\mathrm{Cu} 3$ & $98.9(5)$ & $98.8(6)$ \\
\hline & & & & $\mathrm{Cu} 3-\mathrm{HO} 10-\mathrm{Cu} 1$ & $103.4(5)$ & $103.3(6)$ \\
\hline
\end{tabular}


Tab. 3 Selected geometrical parameters (bond lengths, $\AA$; and angles, ${ }^{\circ}$ ) in the structure of DEM

\begin{tabular}{|c|c|c|c|c|c|c|}
\hline & & $-173^{\circ} \mathrm{C}$ & $87^{\circ} \mathrm{C}$ & & $-173{ }^{\circ} \mathrm{C}$ & $87^{\circ} \mathrm{C}$ \\
\hline $\mathrm{U} 1-\mathrm{O} 1$ & & $1.777(7)$ & $1.772(8)$ & $\mathrm{Cu} 3-\mathrm{O} 7$ & $2.049(7)$ & $2.060(8)$ \\
\hline $\mathrm{U} 1-\mathrm{O} 2$ & & $1.792(7)$ & $1.780(8)$ & $\mathrm{Cu} 3-\mathrm{O} 10$ & $2.025(7)$ & $2.041(8)$ \\
\hline$<\mathrm{U} 1-\mathrm{O}_{U r}>$ & & 1.785 & 1.776 & $\mathrm{Cu} 3-\mathrm{HO} 12$ & $2.366(6)$ & $1.950(7)$ \\
\hline U1-O3 & & $2.393(6)$ & $2.394(6)$ & $\mathrm{Cu} 3-\mathrm{HO} 12$ & $1.956(6)$ & $2.372(7)$ \\
\hline $\mathrm{U} 1-\mathrm{O} 5$ & & $2.465(6)$ & $2.477(6)$ & $\mathrm{Cu} 3-\mathrm{HO} 13$ & $1.958(6)$ & $1.944(7)$ \\
\hline $\mathrm{U} 1-\mathrm{O} 6$ & & $2.355(6)$ & $2.361(7)$ & $\mathrm{Cu} 3-\mathrm{H}_{2} \mathrm{O} 15$ & $2.386(7)$ & $2.407(9)$ \\
\hline $\mathrm{U} 1-\mathrm{O} 8$ & & $2.349(7)$ & $2.363(7)$ & $<\mathrm{Cu} 3-\mathrm{O}>$ & 2.123 & 2.129 \\
\hline U1-O9 & & $2.374(6)$ & $2.377(6)$ & & & \\
\hline$<\mathrm{U} 1-\mathrm{O}_{e q}>$ & & 2.387 & 2.394 & U1-O3-Se1 & $119.6(4)$ & $120.5(4)$ \\
\hline $\mathrm{Se} 1-\mathrm{O} 3$ & & $1.719(6)$ & $1.710(7)$ & U1-O5-Se1 & $125.2(3)$ & $125.7(3)$ \\
\hline $\mathrm{Se} 1-\mathrm{O} 4$ & & $1.699(6)$ & $1.709(6)$ & U1-O6-Se2 & 139.1(4) & $140.2(5)$ \\
\hline $\mathrm{Se} 1-\mathrm{O} 5$ & & $1.719(7)$ & $1.716(7)$ & $\mathrm{U} 1-\mathrm{O} 8-\mathrm{Se} 2$ & $144.3(4)$ & $143.5(5)$ \\
\hline$<\mathrm{Se} 1-\mathrm{O}\rangle$ & & 1.712 & 1.712 & U1-O9-Se3 & $124.9(3)$ & $126.5(4)$ \\
\hline Se2-O6 & & $1.710(6)$ & $1.694(7)$ & $\mathrm{Se} 1-\mathrm{O} 4-\mathrm{Pb} 1$ & $125.0(3)$ & $124.0(3)$ \\
\hline $\mathrm{Se} 2-\mathrm{O} 7$ & & $1.710(6)$ & $1.703(6)$ & $\mathrm{Se} 1-\mathrm{O} 4-\mathrm{Cu} 2$ & $130.0(4)$ & $130.3(4)$ \\
\hline $\mathrm{Se} 2-\mathrm{O} 8$ & & $1.691(7)$ & $1.680(9)$ & $\mathrm{Se} 1-\mathrm{O} 5-\mathrm{Pb} 1$ & $121.6(3)$ & $121.8(3)$ \\
\hline$<\mathrm{Se} 2-\mathrm{O}>$ & & 1.704 & 1.692 & $\mathrm{Se} 2-\mathrm{O} 7-\mathrm{Cu} 1$ & $129.8(4)$ & $130.0(4)$ \\
\hline Se3-O9 & & $1.687(7)$ & $1.673(8)$ & $\mathrm{Se} 2-\mathrm{O} 7-\mathrm{Cu} 3$ & $120.9(4)$ & $122.1(5)$ \\
\hline Se3-O10 & & $1.708(6)$ & $1.705(7)$ & $\mathrm{Se} 3-\mathrm{O} 10-\mathrm{Cu} 1$ & $138.3(3)$ & $137.8(4)$ \\
\hline $\mathrm{Se} 3-\mathrm{O} 11$ & & $1.725(6)$ & $1.712(6)$ & $\mathrm{Se} 3-\mathrm{O} 10-\mathrm{Cu} 3$ & $116.8(4)$ & $116.6(4)$ \\
\hline$<$ Se3-O $>$ & & 1.707 & 1.697 & $\mathrm{Se} 3-\mathrm{O} 11-\mathrm{Pb} 1$ & $107.9(3)$ & $108.4(3)$ \\
\hline $\mathrm{Pb} 1-\mathrm{O} 4$ & & $2.748(6)$ & $2.754(7)$ & $\mathrm{Se} 3-\mathrm{O} 11-\mathrm{Cu} 2$ & $122.1(3)$ & $123.0(3)$ \\
\hline $\mathrm{Pb} 1-\mathrm{O} 5$ & & $2.642(6)$ & $2.644(7)$ & $\mathrm{Se} 3-\mathrm{O} 11-\mathrm{Cu} 2$ & $116.1(4)$ & $116.0(4)$ \\
\hline $\mathrm{Pb} 1-\mathrm{O} 6$ & & $2.932(6)$ & $2.924(7)$ & $\mathrm{Cu} 2-\mathrm{O} 4-\mathrm{Pb} 1$ & $99.1(2)$ & $100.3(2)$ \\
\hline $\mathrm{Pb} 1-\mathrm{O} 7$ & & $3.068(7)$ & $3.085(7)$ & $\mathrm{Cu} 3-\mathrm{O} 7-\mathrm{Cu} 1$ & $102.8(2)$ & $102.2(2)$ \\
\hline $\mathrm{Pb} 1-\mathrm{O} 10$ & & $2.934(6)$ & $2.949(7)$ & $\mathrm{Cu} 3-\mathrm{O} 10-\mathrm{Cu} 1$ & $95.2(2)$ & $95.0(3)$ \\
\hline $\mathrm{Pb} 1-\mathrm{O} 11$ & & $2.536(6)$ & $2.567(6)$ & $\mathrm{Cu} 2-\mathrm{O} 11-\mathrm{Pb} 1$ & $98.1(2)$ & $97.4(2)$ \\
\hline $\mathrm{Pb} 1-\mathrm{HO} 13$ & & $2.376(6)$ & $2.390(7)$ & $\mathrm{Cu} 2-\mathrm{O} 11-\mathrm{Pb} 1$ & $105.9(2)$ & $105.4(2)$ \\
\hline $\mathrm{Pb} 1-\mathrm{HO} 14$ & & $2.484(6)$ & $2.496(7)$ & $\mathrm{Cu} 2-\mathrm{O} 11-\mathrm{Cu} 2$ & $104.3(3)$ & $103.9(3)$ \\
\hline $\mathrm{Pb} 1-\mathrm{H}_{2} \mathrm{O} 15$ & & $3.099(8)$ & $3.111(10)$ & $\mathrm{Cu} 1-\mathrm{HO} 12-\mathrm{Cu} 3$ & $100.5(2)$ & $101.7(2)$ \\
\hline$<\mathrm{Pb} 1-\mathrm{O}>$ & & 2.758 & 2.769 & $\mathrm{Cu} 1-\mathrm{HO} 12-\mathrm{Cu} 3$ & $107.5(3)$ & $107.6(3)$ \\
\hline $\mathrm{Cu} 1-\mathrm{O} 7$ & $\times 2$ & $2.193(7)$ & $2.240(7)$ & $\mathrm{Cu} 3-\mathrm{HO} 12-\mathrm{Cu} 3$ & $93.5(3)$ & $93.2(3)$ \\
\hline $\mathrm{Cu} 1-\mathrm{O} 10$ & $\times 2$ & $2.222(6)$ & $2.208(7)$ & $\mathrm{Cu} 2-\mathrm{HO} 13-\mathrm{Pb} 1$ & $92.3(2)$ & $92.1(2)$ \\
\hline $\mathrm{Cu} 1-\mathrm{HO} 12$ & $\times 2$ & $1.935(7)$ & $1.933(7)$ & $\mathrm{Cu} 3-\mathrm{HO} 13-\mathrm{Pb} 1$ & $114.3(3)$ & $115.1(3)$ \\
\hline$<\mathrm{Cu} 1-\mathrm{O}>$ & & 2.117 & 2.127 & $\mathrm{Cu} 3-\mathrm{HO} 13-\mathrm{Cu} 2$ & $130.3(4)$ & $130.5(4)$ \\
\hline $\mathrm{Cu} 2-\mathrm{O} 4$ & & $1.984(6)$ & $1.978(6)$ & $\mathrm{Cu} 2-\mathrm{HO} 14-\mathrm{Pb} 1$ & $112.1(3)$ & $112.4(3)$ \\
\hline $\mathrm{Cu} 2-\mathrm{O} 11$ & & $2.380(6)$ & $2.403(7)$ & $\mathrm{Cu} 2-\mathrm{HO} 14-\mathrm{Pb} 1$ & $101.8(2)$ & $102.5(3)$ \\
\hline $\mathrm{Cu} 2-\mathrm{O} 11$ & & $2.003(6)$ & $2.026(7)$ & $\mathrm{Cu} 2-\mathrm{HO} 14-\mathrm{Cu} 2$ & $98.3(3)$ & $98.3(3)$ \\
\hline $\mathrm{Cu} 2-\mathrm{HO} 13$ & & $2.426(7)$ & $2.452(7)$ & & & \\
\hline $\mathrm{Cu} 2-\mathrm{HO} 14$ & & $1.982(6)$ & $1.956(7)$ & & & \\
\hline $\mathrm{Cu} 2-\mathrm{HO} 14$ & & $1.956(7)$ & $1.989(6)$ & & & \\
\hline$<\mathrm{Cu} 2-\mathrm{O}>$ & & 2.122 & 2.134 & & & \\
\hline
\end{tabular}

like the fourth vertex of the regular tetrahedron. All four $\mathrm{O}_{e q}$ atoms are shared with the $\left[\mathrm{SeO}_{3}\right]^{2-}$ groups, whereas each selenite group has only two $\mathrm{O}$ atoms shared with two neighbors $U r$, which results in the formation of an infinite chain as the main structure building block (Fig. 2a). Chains pass along the [001] and the equatorial planes of $U r$ tetragonal bipyramids are arranged parallel to the (101). There are three crystallographically non-equivalent $\mathrm{Cu}$ atoms in the structure of DER, which possess distorted octahedral coordination with nearly square equatorial plane of $\mathrm{OH}^{-}$groups and elongated apical contacts with $\mathrm{O}$ atoms due to the JahnTeller effect. Each $\mathrm{Cu}$ atom shares its equatorial hydroxyl groups with the neighbor $\mathrm{Cu}$ atoms, forming tri-octahedral layers (Fig. 2c) parallel to (010). Copper-oxygen layers are linked with uranyl selenite chains through the trans- arranged apical $\mathrm{O}$ atoms, which are the third vertices of selenite groups nonshared with $U r$ (Fig. 3). Additional linkage is made through the H-bonding system, which involves hydroxyl groups from the $\mathrm{Cu}-\mathrm{O}$ layer and both $\mathrm{O}_{U r}$ and $\mathrm{O}_{e q}$ from the U-bearing chains $(\mathrm{OH} 7 \cdots \mathrm{O} 3, \mathrm{OH} 8 \cdots \mathrm{O} 1$, $\mathrm{OH} 9 \cdots \mathrm{O} 5, \mathrm{OH} 10 \cdots \mathrm{O} 5)$. Stereochemically active lone-electron pairs of the $\mathrm{Se}^{4+}$ cations are directed towards the neighbor uranyl selenite chains.

Uranyl selenite chain in the structure of DER corresponds to one of the simplest and common $c c 1-1: 2-1$ topological types (Fig. 2b). Its graph can be described as an infinite chain of 4-membered vertex-sharing rings (Krivovichev 2008). For instance, the same topology was observed in the structure of kröhnkite, $\mathrm{Na}_{2} \mathrm{Cu}\left(\mathrm{SO}_{4}\right)_{2}\left(\mathrm{H}_{2} \mathrm{O}\right)_{2}$ (Hawthorne and Ferguson 1975), uranyl sulfate mineral rietveldite, $\mathrm{Fe}\left(\mathrm{UO}_{2}\right)\left(\mathrm{SO}_{4}\right)_{2}\left(\mathrm{H}_{2} \mathrm{O}\right)_{5}$ (Kampf et al. 2017) and its $\mathrm{Mg}$-bearing synthetic analogs $\mathrm{Mg}\left[\left(\mathrm{UO}_{2}\right)\left(\mathrm{TO}_{4}\right)_{2}\left(\mathrm{H}_{2} \mathrm{O}\right)\right]\left(\mathrm{H}_{2} \mathrm{O}\right)_{4}(T=\mathrm{S}, \mathrm{Se})$ (Gurzhiy et al. 2019b). 

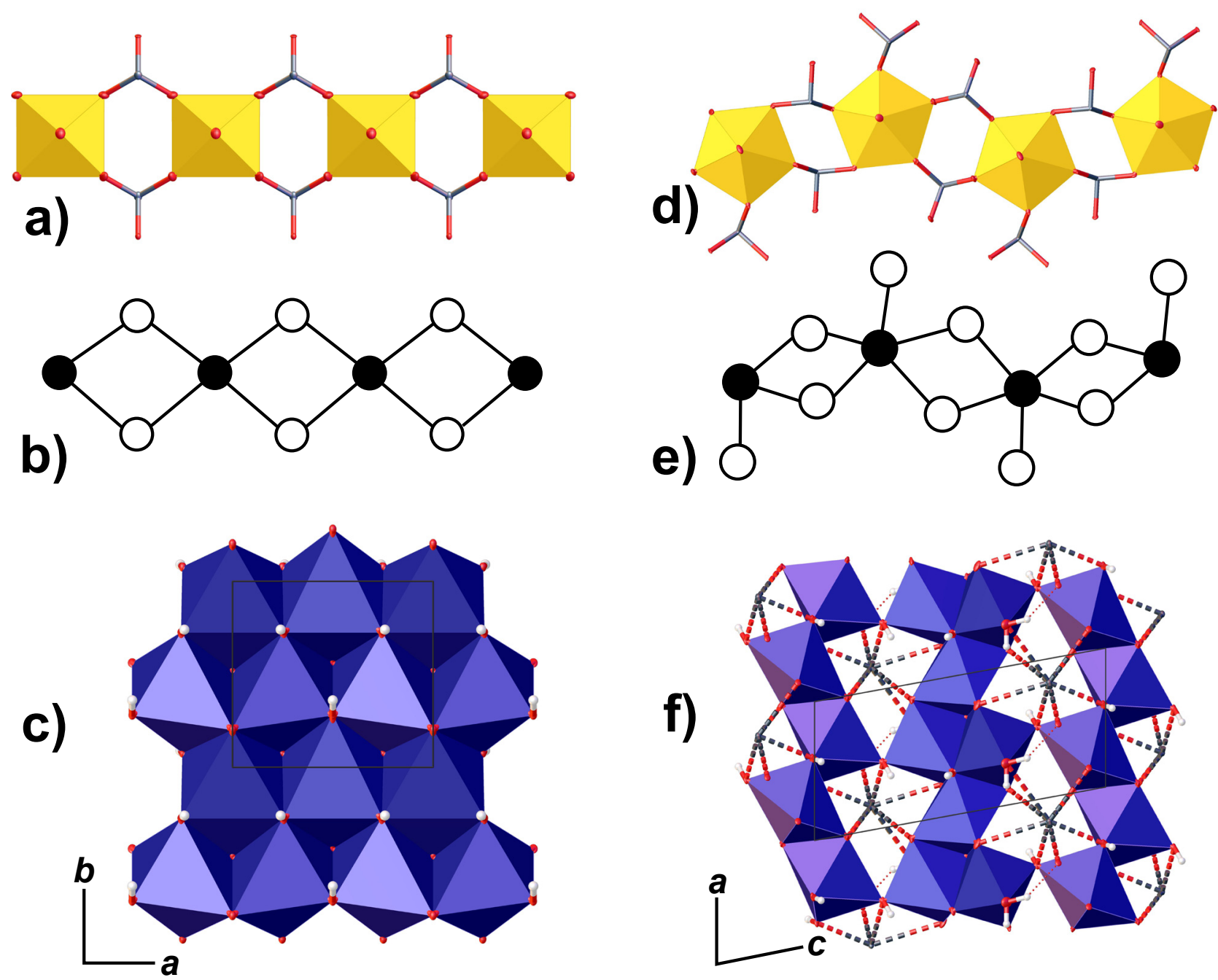

Fig. 2 a - Uranyl selenite chain in the structure of DER. $\mathbf{b}$ - its graphical representation. $\mathbf{c}$ - trioctahedral layer in the structure of DER built by $\mathrm{Cu}$-centered $\left[\mathrm{CuO}_{2}(\mathrm{OH})_{4}\right]$ complexes. d - uranyl selenite chain in the structure of DEM, and $\mathbf{e}$ - its graphical representation. $\mathbf{f}-$ interstitial layer built by $\mathrm{Cu}$-centered octahedra and Pb-centered nine-fold polyhedra in the structure of DEM. Color scheme: $\mathrm{U}$ polyhedra $=$ yellow; $\mathrm{Cu}$ polyhedra $=$ dark blue; $\mathrm{Se}, \mathrm{Pb}$ and $\mathrm{O}$ atoms are grey, dark grey and red, respectively; hydrogen atoms are small white circles; $\mathrm{Pb}-\mathrm{O}$ bonds $=$ dark grey stippled cones; black nodes $=\mathrm{U}$ atoms, white nodes $=\mathrm{Se}$ atoms .

There is one symmetrically unique $\mathrm{U}$ atom in the structure of DEM, forming $U r$ with two short $\mathrm{U}^{6+} \equiv \mathrm{O}^{2-}$ bonds and another five $\mathrm{O}_{e q}$ atoms that belong to selenite groups, to form a pentagonal bipyramid as a coordination polyhedron of U atoms (Tab. 3). There are three crystallographically non-equivalent Se atoms in the structure of DER arranged in the apical vertices of trigonal pyramids, surrounded by three $\mathrm{O}$ atoms. $\mathrm{Se} 1-$ and $\mathrm{Se} 2$-centered groups have two $\mathrm{O}$ atoms shared with two neighboring $U r$, while the third Se3-centered group has only one $\mathrm{O}$ atom shared with $U r$, which results in the formation of infinite uranyl selenite 1D unit (Fig. 2d). The $U r$ shares four $\mathrm{O}_{e q}$ atoms with 2-connected selenite groups, and the fifth vertex is occupied by another 1-connected $\left[\mathrm{SeO}_{3}\right]^{2-}$ pyramid. Uranyl selenite 1D units are arranged along the [101], having the equatorial planes of $U r$ pentagonal bipyramids being parallel to (101). Chains are stacked one above the other, forming blocks parallel to (010) (Fig. 4). These blocks, in turn, are separated by the sheets of edge-shared $\mathrm{Cu}$ - and $\mathrm{Pb}$-centered coordination polyhedra (Fig. 2f). There are three crystallographically non-equivalent $\mathrm{Cu}$ atoms in the structure of DEM, which possess three different coordination geometries $\left[\mathrm{Cu} 1 \mathrm{O}_{4}(\mathrm{OH})_{2}\right]^{8-},\left[\mathrm{Cu} 2 \mathrm{O}_{3}(\mathrm{OH})_{3}\right]^{7-}$ and $\left[\mathrm{Cu} 3 \mathrm{O}_{2}(\mathrm{OH})_{3}\left(\mathrm{H}_{2} \mathrm{O}\right)\right]^{6-}$, and one non-equivalent $\mathrm{Pb}^{2+}$ cation is arranged in the center of ninefold $\left[\mathrm{PbO}_{6}(\mathrm{OH})_{2}\left(\mathrm{H}_{2} \mathrm{O}\right)\right]^{12-}$ complex. $\mathrm{Cu} 1$ atoms possess $(2+4)$ distorted geometry, while $\mathrm{Cu} 2$ and $\mathrm{Cu} 3$ atoms have $(4+2)$ coordination, which is considered to be more stable. Hathaway (1984) have shown that $\mathrm{Cu}^{2+}$-bearing polyhedra with the $(2+4)$ geometry may be the case of the dynamic Jahn-Teller effect of a series of $(4+2)$ complexes that are rapidly interchanging at various temperatures. However, we did not find such an effect within current data. $\mathrm{Cu}$-centered polyhedra form two types of chains directed along the 

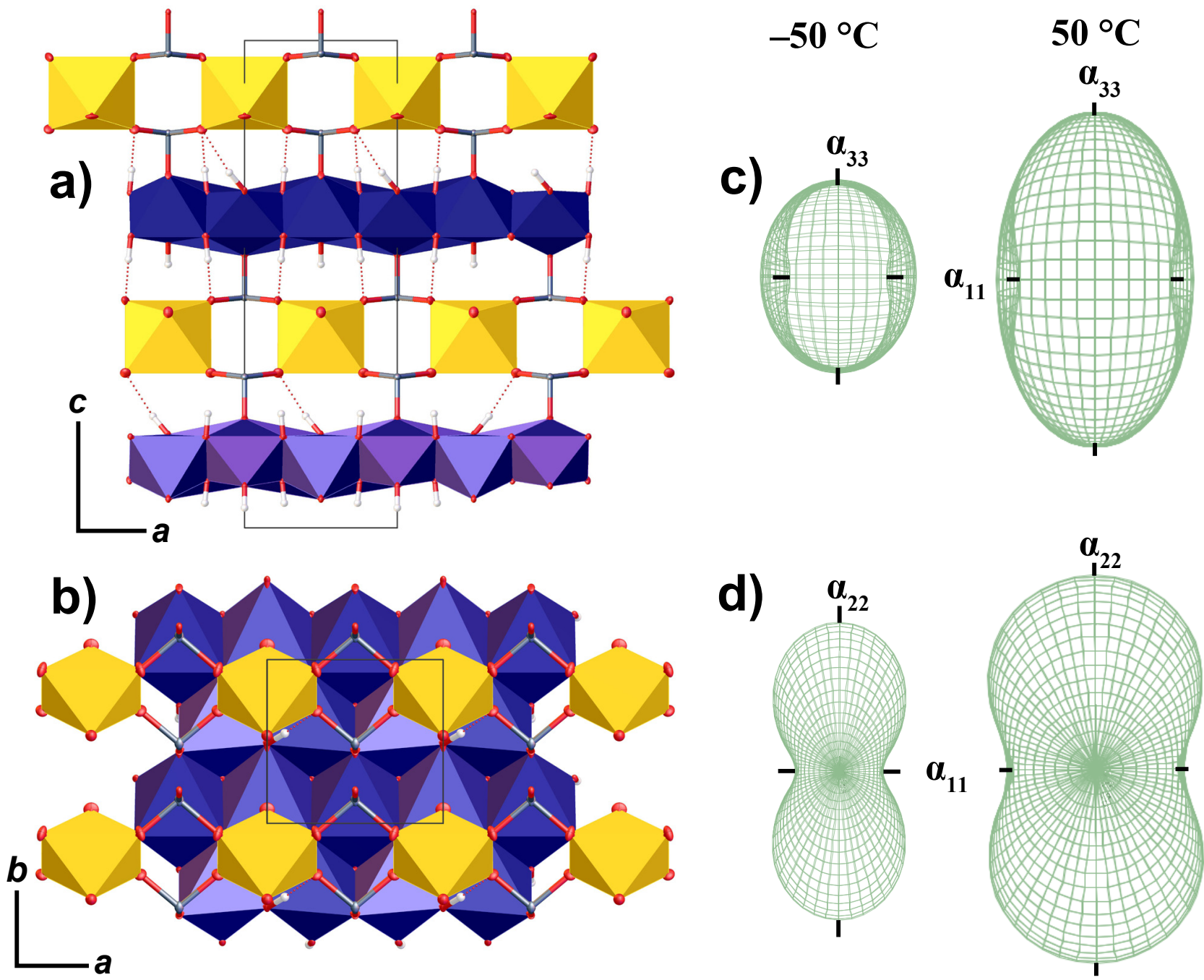

Fig. 3 The crystal structure of DER. a - projected along the $b$ axis. b-projected along the $c$ axis (b). c, d - the arrangement of figures of thermal expansion/contraction coefficients (TEC) relative to the structure projections. Color scheme same as in Fig. 2; TEC figures: expansion $=$ green, contraction $=$ red.

[100] and linked together via $\mathrm{Pb}$-centered complexes and a common $\mathrm{O} 13 \mathrm{H}$ group. The first type is formed by the alternating ...-one $\mathrm{Cu} 1$-two $\mathrm{Cu} 3$-one $\mathrm{Cu} 1$-two $\mathrm{Cu} 3-\ldots$ octahedra with an edge-sharing linkage. There, the $\mathrm{Cu} 1$ octahedron shares four of its edges with four $\mathrm{Cu} 3$ polyhedra, and $\mathrm{Cu} 3$ shares two edges with two $\mathrm{Cu} 1$ octahedra, one edge with neighboring Cu3. This type of connection is a shortcutting of the trioctahedral layer in DER. The second type is a narrow, one octahedron wide chain built by $\mathrm{Cu} 2$-centered polyhedra that are connected only through the two common edges.

The topology of the U-Se chain in the structure of DEM belongs to the $c c 1-1: 3-2$ type (Krivovichev 2008) and has some similarities with that for DER (vertexsharing infinite chain of 4-membered rings), but also has a very distinct difference in the additional 1-connected selenite group to each $U r$ (Fig. 2e), which makes this topology relatively rare. It has been observed in a few struc- tures of exclusively synthetic U-bearing compounds, e.g. $\left(\mathrm{C}_{2} \mathrm{H}_{8} \mathrm{~N}\right)_{3}\left[\left(\mathrm{UO}_{2}\right)\left(\mathrm{SeO}_{4}\right)_{2}\left(\mathrm{HSeO}_{4}\right)\right]$ (Gurzhiy et al. 2017).

It should be noted that derriksite and demesmaekerite are the only uranyl selenite minerals, which structures are built upon infinite 1D U-bearing units. Crystal structures of guilleminite, marthozite, haynesite, piretite, and larisaite are based on dense uranyl selenite layers of the phosphuranylite topology (Demartin et al. 1991; Gurzhiy et al. 2019a).

\subsection{Thermal Behavior}

There is a beahvior of the unit-cell parameters of DER versus temperature shown in Figure 5. All parameters are gradually increasing with temperature. However, $a$ unit cell parameter grows very slowly and $b$, on the contrary, rises sharply. Equations describing the temperature dependence of the unit cell parameters of DER within the 
a)

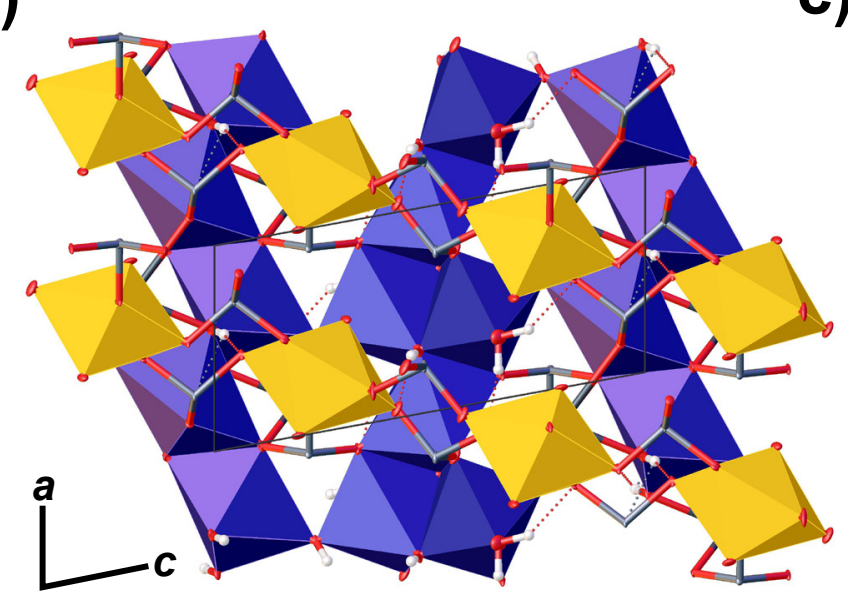

b)

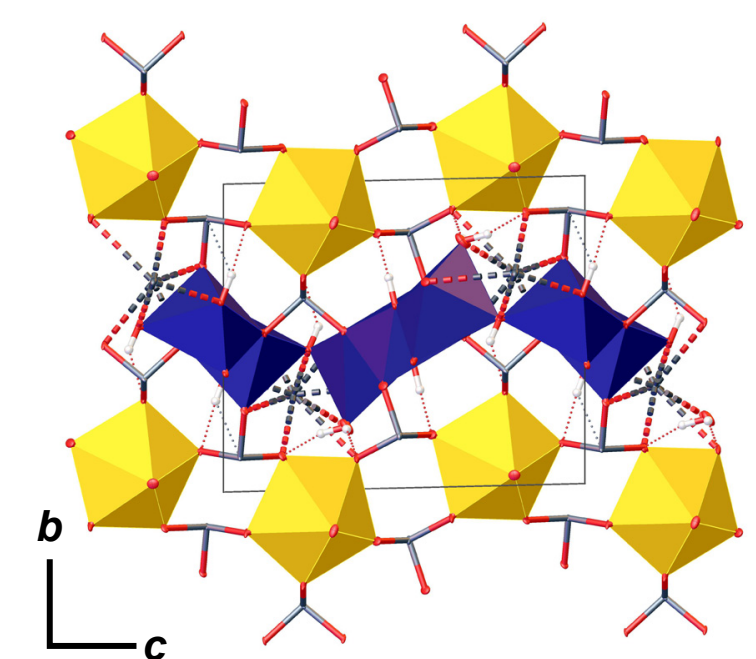

C)
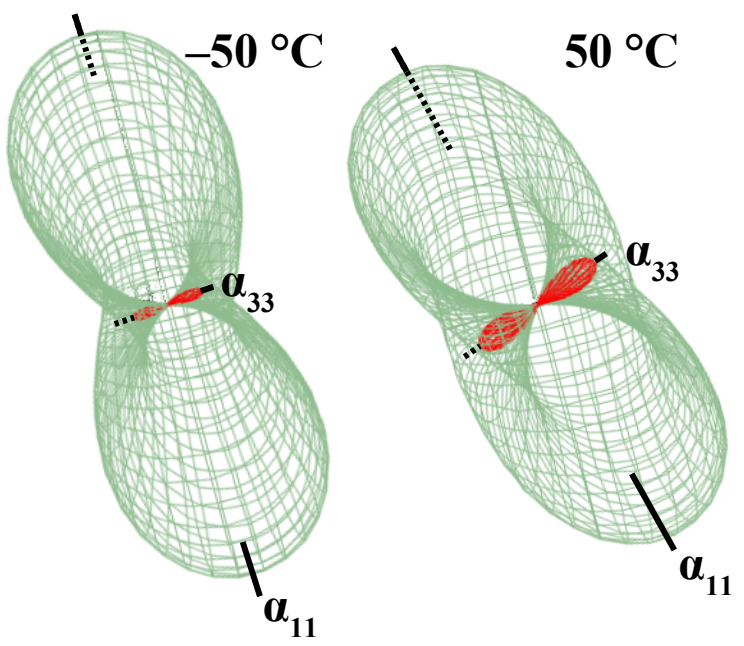

d)
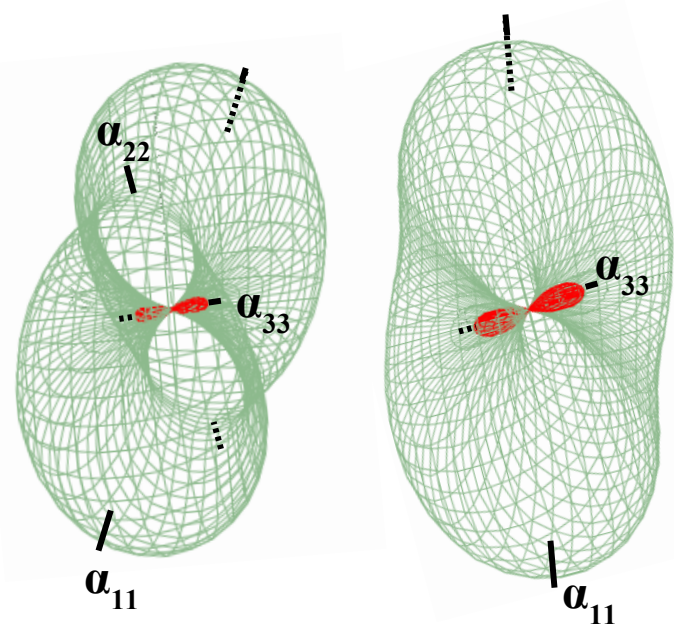

Fig. 4 The crystal structure of DEM. a - projected along the $b$ axis. $\mathbf{b}$ - projected along the $a$ axis (b). c, d - the arrangement of figures of thermal expansion/contraction coefficients (TEC) relative to the structure projections. Color scheme same as in Figs. 2 and 3.

range of -173 to $87^{\circ} \mathrm{C}$ are: $a=5.972+8.278 \times 10^{-5} \times T$ $+3.399 \times 10^{-7} \times T^{2} ; b=5.569+2.276 \times 10^{-4} \times T+6.486$ $\times 10^{-7} \times T^{2} ; c=19.084+5.154 \times 10^{-4} \times T+2.158 \times 10^{-6}$ $\times T^{2}$; and $V=634.7+52.8 \times 10^{-3} \times T+1.9 \times 10^{-4} \times T^{2}$.

The Fig. 6 shows the behavior of the unit-cell parameters of DEM as a function of temperature. The dependence here is not so regular and more complicated than it was observed for DER. The largest increase is observed for the $a$ unit-cell parameter, while the $c$ decreases with temperature increase, although slightly. There are also different characters of functions are observed for various parameters. Thus, $b$ and $\beta$ are described by nearly exponential growth; $a, \alpha$ and $\gamma$ functions flatten out with temperature increase, while the $c$ is described by decreasing almost linear function. Equations describing the temperature dependence of the unit-cell parameters of DEM within the range of -173 to $87^{\circ} \mathrm{C}$ are: $a=5.661+1.139$ $\times 10^{-4} \times T-3.204 \times 10^{-7} \times T^{2} ; b=10.069+2.140 \times 10^{-4}$ $\times T+2.689 \times 10^{-7} \times T^{2} ; c=11.976-3.657 \times 10^{-5} \times T+$ $4.328 \times 10^{-8} \times T^{2} ; \alpha=88.66+1.506 \times 10^{-4} \times T-4.415 \times$ $10^{-7} \times T^{2} ; \beta=79.63+9.491 \times 10^{-4} \times T+2.983 \times 10^{-6} \times$ $T^{2} ; \gamma=89.88+8.353 \times 10^{-4} \times T-1.120 \times 10^{-6} \times T^{2}$; and $V=671.3+27.9 \times 10^{-3} \times T-1.3 \times 10^{-5} \times T^{2}$.

The thermal behavior of DER and DEM has a substantially anisotropic character (Tab. 4). The general theory of thermal behavior (Filatov 1990, 2011; Hazen and Downs 2001) of crystalline compounds points out that the maximal thermal expansion should be along the weakest bonding direction.

Two types of solid constructions can be distinguished in the crystal structures of derriksite and demesmaekerite. Those are uranyl selenite chains and interstitial layers built by $\mathrm{Cu}$ - and $\mathrm{Pb}$-centered polyhedra. Thus, one could expect the directions of these units' arrangement to be the least prone to expansion. This is actually observed in the structure of DER. The lowest expansion occurs 


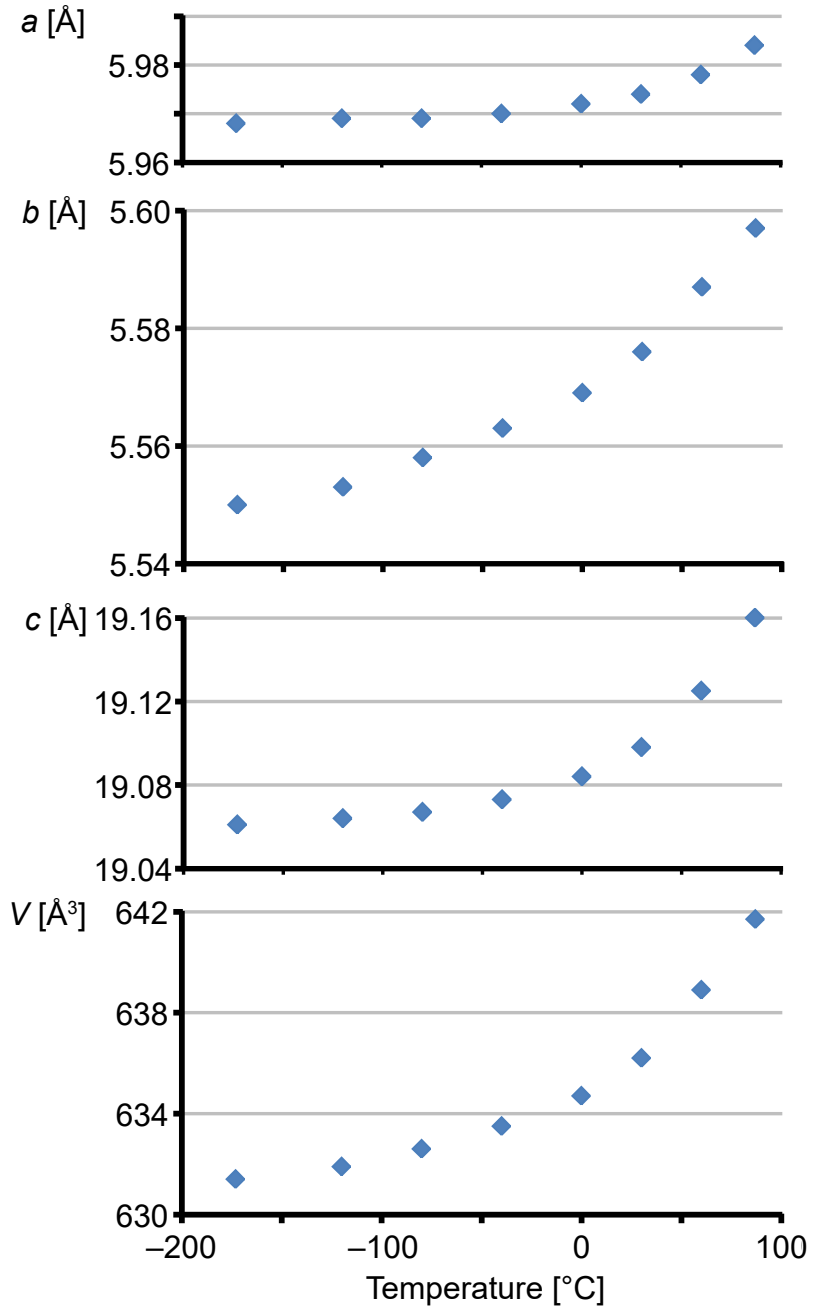

Fig. 5 Unit-cell parameters of DER as a function of temperature $(-173$ to $+87^{\circ} \mathrm{C}$ ) in liquid nitrogen flow (an estimated standard deviations, ESDs, of the unit-cell parameters are within the limits of the symbols).

along the [100], which coincides with the uranyl selenite chain elongation. Uranyl tetragonal bipyramids, selenite groups, and $\mathrm{Cu}$ octahedra undergo relatively the same expansion, which can be seen from Tab. 2. Hence, the $\mathrm{Cu}-$ bearing layer contributes equally to the rigidity along the [100] and [010]. Linkage of uranyl selenite chains with the $\mathrm{Cu}$-bearing layers via covalent and H-bonding systems provides additional rigidity along the [001]. Strong covalent bonding along the [010] occurs only within the octahedral layer, while there is no connection between the U-bearing chains, which causes the largest expansion in this direction. It should also be mentioned that some of the cis $\mathrm{Cu}-\mathrm{O}-\mathrm{Cu}$ angular parameters decrease with temperature, which can be attributed to the response of the dense structure of trioctahedral layer to the increase of $\mathrm{Cu}-\mathrm{O}$ bond lengths.

The thermal expansion dynamics in the structure of DEM is more challenging to trace. The first thing that should be worth noting is the change in the orientation of the figure of the TEC with heating. For instance, at low temperatures $\alpha_{33}$ coefficient, which corresponds to the contraction of the structure, almost coincides with the [001], and then it shifts towards the solid diagonal of the unit cell. Although this direction corresponds to the space between the uranyl selenite chains with the deficiency of strong bonds, the contraction of the structure and rotation of the figure of the TEC should be mainly attributed to the orthogonalization of the oblique triclinic angles of the unit cell. This effect was described by Filatov (2008) and recently observed in (Izatulina et al. 2018, 2019). Along the [010], the linkage between the U-bearing chains and interlayer $\mathrm{Cu}-\mathrm{Pb}$ complex occurs via sharing $\mathrm{O}$ atoms of the selenite groups, which explains the insignificant expansion of the structure in this direction. Thermal expansion of $\mathrm{U}, \mathrm{Se}, \mathrm{Cu}$ and $\mathrm{Pb}$ coordination polyhedra is equivalent, which can be seen from the dynamics of bond lengths and angles with heating (Tab. 3). The maximal expansion of DER is observed approximately along the [100], which matches the direction of the thin chain of $\mathrm{Cu}$-centered octahedra and gaps between $\mathrm{Cu}$ chains occupied by the $\mathrm{Pb}$ cations.

\section{Conclusions}

As the result for derriksite, $\mathrm{Cu}_{4}\left[\left(\mathrm{UO}_{2}\right)\left(\mathrm{SeO}_{3}\right)_{2}\right](\mathrm{OH})_{6}$, and demesmaekerite, $\mathrm{Pb}_{2} \mathrm{Cu}_{5}\left[\left(\mathrm{UO}_{2}\right)_{2}\left(\mathrm{SeO}_{3}\right)_{6}(\mathrm{OH})_{6}\right]\left(\mathrm{H}_{2} \mathrm{O}\right)_{2}$, crystal structures refinement in the temperature range of -173 to $+87^{\circ} \mathrm{C}$, thermal behavior of their structures was analyzed. In general, the lowest expansion is observed along the direction of uranyl selenite chains, while the largest expansion occurs in the direction normal or inclined to chains, with the low covalent bond distribution density. The crystal structure of demesmaekerite undergoes a contraction of the 


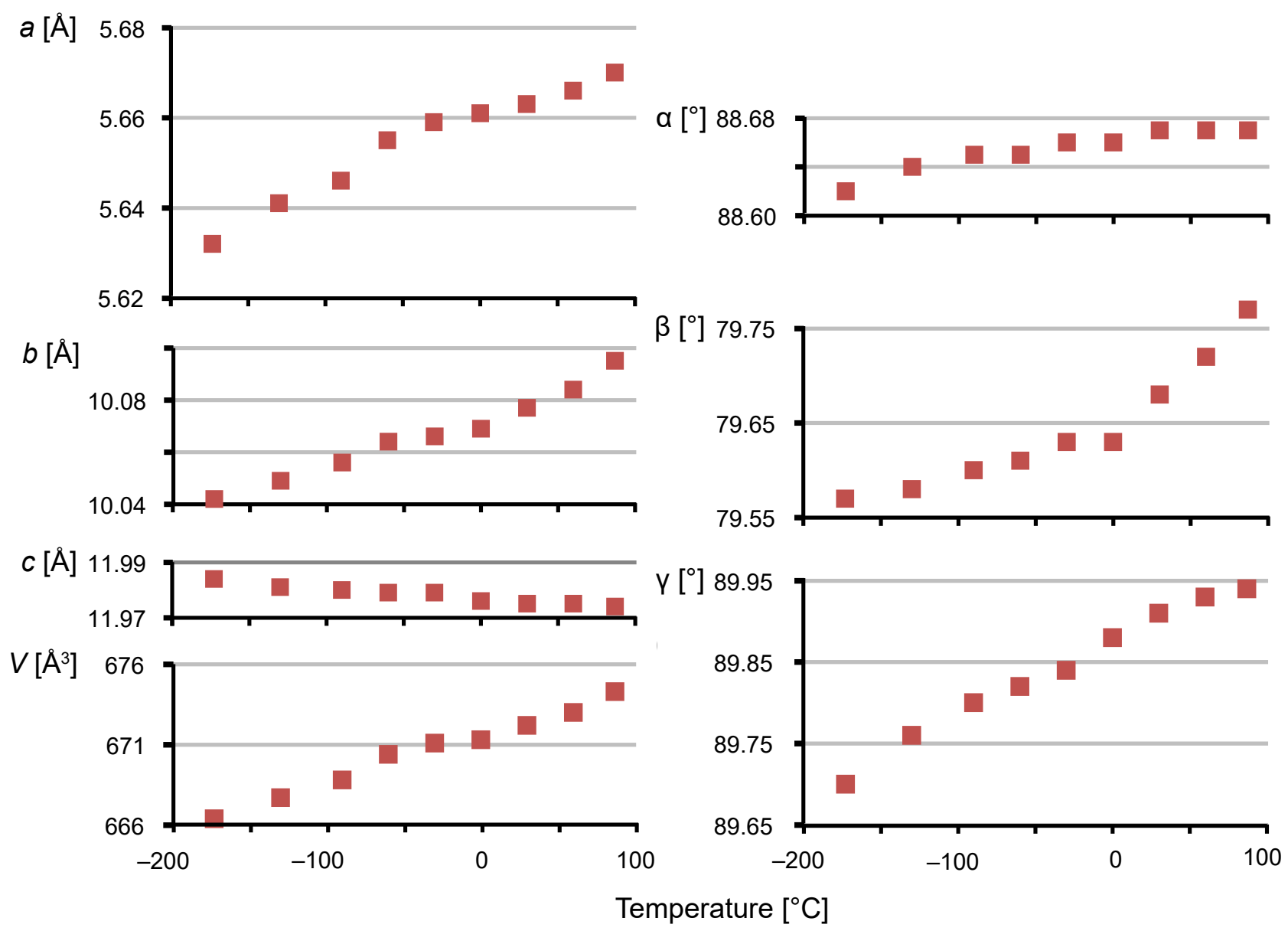

Fig. 6 Unit-cell parameters of DEM as a function of temperature $\left(-173\right.$ to $\left.+87^{\circ} \mathrm{C}\right)$ in liquid nitrogen flow (ESDs of the unit cell parameters are within the limits of the symbols).

structure during heating, which can be attributed to the orthogonalization of the oblique angles of the triclinic unit cell.

The results of current study allow to expand the common crystal chemical borders of the $\mathrm{U}^{6+}$-bearing minerals and to estimate rather rarely studied parameters such as the strength characteristics of crystal structures. By the current study, it has been documented that uranyl complexes are one of the most stable and rigid blocks in the structural architecture of natural and synthetic uranyl compounds, and they govern the thermal behavior of the whole structure, which is in agreement with the results of recent studies (Gurzhiy et al. 2018, 2020; Kornyakov et al. 2019). These conclusions are valid, regardless of:

1) the dimensionality of $U^{6+}$-bearing substructural units,

2) both the arrangement and the chemical composition of an interlayer structure.

These observations reasonably justifies an assignment of $\mathrm{U}^{6+}$-bearing units as the fundamental building blocks (FBB) of the entire crystal structures of $\mathrm{U}^{6+}$-compounds and justifies the structural hierarchies based on these FBB (Burns 1999, 2005; Lussier et al. 2016).
Acknowledgments. This research was funded by the Russian Science Foundation (grant 18-17-00018). The XRD and EDX measurements have been performed at the X-ray Diffraction Centre and "Geomodel" Research Centre of the St. Petersburg State University. We are grateful to two anonymous reviewers for useful comments.

Electronic supplementary material. Supplementary crystallographic data are available online at the Journal web site (http://dx.doi.org/10.3190/jgeosci.315).

\section{References}

BuRns PC (1999) The crystal chemistry of uranium. In: Uranium: Mineralogy, Geochemistry and the Environment. Rev Mineral 38: 23-90

BuRns PC (2005) $\mathrm{U}^{6+}$ minerals and inorganic compounds: insights into an expanded structural hierarchy of crystal structures. Canad Mineral 43: 1839-1894 
Cesbron F, Bachet B, Oosterbosch R (1965) La demesmaekerite, sélénite hydraté d'uranium, cuivre et plomb. Bull Soc franc Minéral Cristallogr 88: 422-425

Cesbron F, Oosterbosch R, Pierrot R (1969) Une nouvelle espèce minérale: la marthozite. Uranyl-sélénite de cuivre hydraté. Bull Soc franc Minéral Cristallogr 92: 278-283

Cesbron F, Pierrot R, Verbeek T (1971) La derriksite, $\mathrm{Cu}_{4}\left(\mathrm{UO}_{2}\right)\left(\mathrm{SeO}_{3}\right)_{2}(\mathrm{OH})_{6} \cdot \mathrm{H}_{2} \mathrm{O}$, une nouvelle espèce minérale. Bull Soc franc Minéral Cristallogr 94: 534-537

Chukanov NV, Pushcharovsky DYu, Pasero M, Merlino S, Barinova AV, Möckel S, Pekov IV, Zadov AE, DubinchuK VT (2004) Larisaite, $\mathrm{Na}\left(\mathrm{H}_{3} \mathrm{O}\right)$ $\left(\mathrm{UO}_{2}\right)_{3}\left(\mathrm{SeO}_{3}\right)_{2} \mathrm{O}_{2} \cdot 4 \mathrm{H}_{2} \mathrm{O}$, a new uranyl selenite mineral from Repete mine, San Juan County, Utah, U.S.A. Eur J Mineral 16: 367-374

Clark RC, ReID JS (1995) The analytical calculation of absorption in multifaceted crystals. Acta Crystallogr A51: 887-897

CrysAlisPro Software System (2018) version 1.171.39.44; Rigaku Oxford Diffraction: Oxford, UK

Deliens M, Piret P (1991) La haynesite, sélénite hydraté d'uranyle, nouvelle espèce minérale de la Mine Repete, Comté de San Juan, Utah. Canad Mineral 29: 561-564

Demartin F, Diella V, Donzelli S, Gramaccioli CM, PiLATI T (1991) The importance of accurate crystal structure determination of uranium minerals. I. Phosphuranylite $\mathrm{KCa}\left(\mathrm{H}_{3} \mathrm{O}\right)_{3}\left(\mathrm{UO}_{2}\right)_{7}\left(\mathrm{PO}_{4}\right)_{4} \mathrm{O}_{4} \cdot 8 \mathrm{H}_{2} \mathrm{O}$. Acta Crystallogr B47: 439-446

Dolomanov OV, Bourhis LJ, Gildea RJ, Howard JAK, PuschmanN H (2009) OLEX2: A complete structure solution, refinement and analysis program. J appl Crystallogr 42: 339-341

FILATOV SK (1990) Visokotemperaturnaia Kristallohimia (High-Temperature Crystal Chemistry, in Russian). Nedra, Leningrad, Russia, pp 1-288

FILATOV SK (2008) Negative linear thermal expansion of oblique-angle (monoclinic and triclinic) crystals as a common case. Phys Stat Sol B245: 2490-2496

FILATOV SK (2011) General concept of increasing crystal symmetry with an increase in temperature. Crystallogr Rep 56: 953-961

Frost RL, Weier ML, Reddy BJ, ČejkA J (2006) A Raman spectroscopic study of the uranyl selenite mineral haynesite. J Raman Spectros 37: 816-821

Frost RL, Čejka J, Keeffe EC, Dickfos MJ (2008a) Raman spectroscopic study of the uranyl selenite mineral marthozite $\mathrm{Cu}\left[\left(\mathrm{UO}_{2}\right)_{3}\left(\mathrm{SeO}_{3}\right)_{2} \mathrm{O}_{2}\right] \cdot 8 \mathrm{H}_{2} \mathrm{O}$. J Raman Spec, 39: 1413-1418

Frost RL, Reddy BJ, Dickfos MJ (2008b) An application of near infrared and mid-infrared spectroscopy to the study of uranyl selenite minerals: derriksite, demesmaekerite, guilleminite and haynesite. J Near Infrared Spectrosc 16: 455-469
Frost RL, Čejka J, Dickfos MJ (2009a) Raman spectroscopic study of the mineral guilleminite $\mathrm{Ba}\left(\mathrm{UO}_{2}\right)_{3}\left(\mathrm{SeO}_{3}\right)_{2}(\mathrm{OH})_{4} \cdot 3 \mathrm{H}_{2} \mathrm{O}$. J Raman Spectrosc 40: 355-359

Frost RL, Čejka J, Dickfos MJ (2009b) Raman spectroscopic study of the uranyl selenite mineral demesmaekerite $\mathrm{Pb}_{2} \mathrm{Cu}_{5}\left(\mathrm{UO}_{2}\right)_{2}\left(\mathrm{SeO}_{3}\right)_{6}(\mathrm{OH})_{6} \cdot 2 \mathrm{H}_{2} \mathrm{O}$. J Raman Spectrosc 40: 476-480

Frost RL, Čejka J, Scholz R, Lopez A, Theiss FL, XI $\mathrm{Y}$ (2014) Vibrational spectroscopic study of the uranyl selenite mineral derriksite $\mathrm{Cu}_{4}\left[\left(\mathrm{UO}_{2}\right)\left(\mathrm{SeO}_{3}\right)_{2}\right](\mathrm{OH})_{6} \cdot \mathrm{H}_{2} \mathrm{O}$. Spectrochim Acta A 117: 473-477

Ginderow D, Cesbron F (1983a) Structure de la demesmaekerite, $\mathrm{Pb}_{2} \mathrm{Cu}_{5}\left(\mathrm{SeO}_{3}\right)_{6}\left(\mathrm{UO}_{2}\right)_{2}(\mathrm{OH})_{6} \cdot 2 \mathrm{H}_{2} \mathrm{O}$. Acta Crystallogr C39: 824-827

Ginderow D, Cesbron F (1983b) Structure da la derriksite, $\mathrm{Cu}_{4}\left(\mathrm{UO}_{2}\right)\left(\mathrm{SeO}_{3}\right)_{2}(\mathrm{OH})_{6}$. Acta Crystallogr C39: 1605-1607

Gurzhiy VV, Krivovichev SV, Tananaev IG (2017) Dehydration-driven evolution of topological complexity in ethylamonium uranyl selenates. J Solid State Chem 247: 105-112

GurzhiY VV, KRZHizHANOVSKaYA MG, IZATUlina AR, SigMON GE, Krivovichev SV, Burns PC (2018) Structure refinement and thermal stability studies of the uranyl carbonate mineral andersonite, $\mathrm{Na}_{2} \mathrm{Ca}\left[\left(\mathrm{UO}_{2}\right)\left(\mathrm{CO}_{3}\right)_{3}\right] \cdot(5+x)$ $\mathrm{H}_{2} \mathrm{O}$. Minerals 8: 586

Gurzhiy VV, Kuporev IV, Kovrugin VM, MurashKo MN, Kasatkin AV, PlášIl J (2019a) Crystal chemistry and structural complexity of natural and synthetic uranyl selenites. Crystals 9: 639

Gurzhiy VV, Tyumentseva OS, IZATUlina AR, KrivoviCHEV SV, TANANAEV IG (2019b) Chemically induced polytypic phase transitions in the $\mathrm{Mg}\left[\left(\mathrm{UO}_{2}\right)\left(\mathrm{TO}_{4}\right)_{2}\left(\mathrm{H}_{2} \mathrm{O}\right)\right]$ $\left(\mathrm{H}_{2} \mathrm{O}\right)_{4}(T=\mathrm{S}, \mathrm{Se})$ system. Inorg Chem 58: 14760-14768

Gurzhiy VV, Kornyakov IV, Szymanowski JES, FelTON D, Tyumentseva OS, KRZHizhanovsKaya MG, Krivovichev SV, Burns PC (2020) Chemically-induced structural variations of a family of $\mathrm{Cs}_{2}\left[\left(\mathrm{AnO} \mathrm{O}_{2}\right)_{2}\left(\mathrm{TO}_{4}\right)_{3}\right]$ ( $A n=\mathrm{U}, \mathrm{Np} ; T=\mathrm{S}, \mathrm{Se}, \mathrm{Cr}, \mathrm{Mo}$ ) compounds: thermal behavior, calorimetry studies and spectroscopy characterization of Cs uranyl sulfate and selenate. J Solid State Chem 282: 121077

HaTHAWAY BJ (1984) A new look at the stereochemistry and electronic properties of complexes of the copper(II) ion. In: Complex Chemistry. Structure and Bonding, Volume 57. Springer, Berlin, Heidelberg, 55-118

Hawthorne FC, Ferguson RB (1975) Refinement of the crystal structure of kroehnkite. Acta Crystallogr B31: 1753-1755

Hazen RM, Downs RT (2001) Reviews in Mineralogy and Geochemistry, Volume 41: High-Temperature and High-Pressure Crystal Chemistry. Mineralogical Society of America, Washington, DC, USA. pp 1-596 
IzATUlina AR, GURZhiY VV, KRZHIZHANOVSKaya MG, KuZ'mina MA, LeONi M, FranK-KamenetsKaya OV (2018) Hydrated Calcium Oxalates: Crystal Structures, Thermal Stability and Phase Evolution. Cryst Growth Des 18: 5465-5478

Izatulina AR, Gurzhiy VV, Krzhizhanovskaya MG, Chukanov NV, Panikorovski TL (2019) Thermal behavior and phase transition of uric acid and its dihydrate form, the common biominerals uricite and tinnunculite. Minerals 9: 373

Kampf AR, Sejkora J, Witzke T, PlášIl J, ČEJKa J, Nash BP, Marty J (2017) Rietveldite, Fe( $\left.\mathrm{UO}_{2}\right)\left(\mathrm{SO}_{4}\right)_{2}\left(\mathrm{H}_{2} \mathrm{O}\right)_{5}$, a new uranyl sulfate mineral from Giveaway-Simplot mine (Utah, USA), Willi Agatz mine (Saxony, Germany) and Jáchymov (Czech Republic). J Geosci 62: 107-120

Kornyakov IV, GURZHIY VV, SZYMANOWSKi JES, ZHANG L, Perry SN, Krivovichev SV, Burns PC (2019) A novel family of $\mathrm{Np}(\mathrm{VI})$ oxysalts: crystal structures, calorimetry, thermal behavior, and comparison with U(VI) compounds. Cryst Growth Des 19: 2811-2819
Krivovichev SV (2008) Structural Crystallography of Inorganic Oxysalts. Oxford University Press, Oxford, UK, pp 1-303

LANGREITER T, KAHLENBERG V (2015) TEV - a program for the determination and visualization of the thermal expansion tensor from diffraction data. Crystals 5: 143-153

Lussier AJ, Lopez RAK, Burns PC (2016) A revised and expanded structure hierarchy of natural and synthetic hexavalent uranium compounds. Canad Mineral, 54: 177-283

Pierrot R, Toussaint J, Verbeek T (1965) La guilleminite, une nouvelle espèce minérale. Bull Soc franc Minéral Cristallogr 88: 132-135

SHELDRICK GM (2015a) SHELXT - Integrated space-group and crystal structure determination. Acta Crystallogr A71: 3-8

SHELDRICK GM (2015b) Crystal structure refinement with SHELXL. Acta Crystallogr C71, 3-8

Vochten R, Blaton N, Peeters O, Deliens M (1996) Piretite, $\mathrm{Ca}\left(\mathrm{UO}_{2}\right)_{3}\left(\mathrm{SeO}_{3}\right)_{2}(\mathrm{OH})_{4} \cdot 4 \mathrm{H}_{2} \mathrm{O}$, a new calcium uranyl selenite from Shinkolobwe, Shaba, Zaire. Canad Mineral 34: 1317-132 